\title{
THE IMPORTANCE OF LATIN AMERICAN SPACE IN THE INTERNATIONALIZATION OF PORTUGUESE SMES
}

\begin{abstract}
André Brás-dos-Santos
Bras dos santos.a@hotmail.com PhD student in History at Universidade Autónoma de Lisboa (UAL, Portugal), Master in Development and International Cooperation and Graduated in Management. Member of the Research Center for Historical Sciences (CICH) and the Business History Research Center (CEHE) of the Universidade Autónoma de Lisboa (UAL). Has been linked to Portuguese SMEs and to the internationalization of the Portuguese companies through professional channels and academic research. He managed a project linked to the "Rede PME Inovação" of COTEC Portugal, was present in several business missions through the Association of Portugal-China Young Entrepreneurs, and was a consultant in the agro-industrial sector.
\end{abstract}

Joaquim Ramos Silva jrsilva@iseg.ulisboa.pt

Full Professor, Instituto Superior de Economia e Gestão, Universidade de Lisboa (Portugal). PhD in "Analyse et Politique Économiques" by the École des Hautes Études en Sciences Sociales, Paris. Member of the SOCIUS/CSG - Research in Social Sciences and Management, a FCT Center. His research has focused on several topics of international economics and has conducted studies on the global, European, Portuguese and Brazilian economies with an emphasis on the internationalization process of companies and in the development and foundations of economic relations between Portugal and Brazil. Author of numerous publications, including books, book chapters and articles in peer-reviewed journals, among others, in Tourism Management, Business

Process Management Journal, Journal of Business Economics and Management, Journal of Enterprise Information Management, Marine Policy and Technological Forecasting and Social Change.

\begin{abstract}
In the light of the transformation undergone in the last decade by the Portuguese economy, the internationalization of Portuguese companies through exports had a considerable growth, reducing the importance of domestic demand as the main variable in the contribution to GDP, this work addresses the role of SMEs in this process, analyzing the case of their internationalization to the Latin American space. The study is based on an empirical analysis of data resulting from a survey conducted in 2014, period where the transformation became clear, through the responses of 50 internationalized Portuguese SMEs to Latin America, which have been validated. Also, and with a focus on this research, the process was correlated with the relevant theories of internationalization, paving the way for more in-depth and methodologically based studies on this relationship with significant potential, but still little analyzed in the context of the Portuguese economy.
\end{abstract}

\section{Keywords}

SMEs, Latin America, Portuguese internationalization, Exports, FDI

How to cite this article

Brás-dos-Santos, André; Silva, Joaquim Ramos (2020). "The importance of Latin American space in the internationalization of Portuguese SMEs". JANUS.NET e-journal of International Relations, Vol. 11, N. ${ }^{\circ} 1$, May-October 2020. Consulted [online] on the date of the last visit, https://doi.org/10.26619/1647-7251.11.1.6

Article received on August 7, 2019 and accepted for publication on March 10, 2020

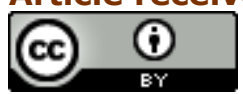




\title{
THE IMPORTANCE OF LATIN AMERICAN SPACE IN THE INTERNATIONALIZATION OF PORTUGUESE SMES
}

\author{
André Brás-dos-Santos \\ Joaquim Ramos Silva
}

\section{Introduction}

The last decade presented a set of profound changes in the Portuguese economy, especially considering the two most negative milestones of its recent economic history: the impact of the global economic crisis triggered in 2007-08 and the subsequent rescue request to the IMF in 2011. It should be noted that the Portuguese gross domestic product (GDP) showed a recession in the period 2010-2015 with an annual rate close to $-1 \%{ }^{1}$. Indeed, the country's economic growth was then in counter-cycle with the recovery seen in most European countries, which showed a modest but effective average growth rate of $0.6 \%$ in the same period. However, as of 2014, Portuguese GDP gradually resumed growth, especially for the years 2016-2018 (respectively, $1.9 \% ; 2.8 \% ; 2.2 \%$ ), even surpassing, after a long period of non-convergence, the average GDP growth rate of the European Union².

Although the changes in the Portuguese economy were not confined to the external sector, the process of the last decade was accompanied by important shifts at this level. Thus, the country's current account registered a turnaround in its performance insofar until the end of the first decade of the XXI century it was clearly in deficit (even reaching $10.2 \%$ of GDP in 2010), unraveling an economic model based on the expansion of domestic demand boosted by imports. Just after, as of 2013, the Portuguese economy showed a surplus in the current account (which represented $1.6 \%$ of GDP in 2013) ${ }^{3}$, showing a shift towards a growth model more supported by an internationalization of firms and activities. Moreover, from 2013 to 2017, the current account registered 5 consecutive years with a surplus, respectively, as a percentage of GDP, of $1.6 \% ; 0.1 \%$; $0.1 \% ; 0.6 \% ; 0.5 \%{ }^{4}$, numerical values with little significance, but striking from the point of view of the historical trend. It is true that in 2013-14, this surplus may also have resulted from the fall in imports caused by the recession and the policy measures associated to overcome it, but its persistence over a wider period and in quite different economic situations can create conditions for more structural changes.

It is important to note that, in light of the experience of the last decades, and towards an approximation to the existing model in European economies of comparable size, the change in the current account (which, incidentally, could be illustrated at other levels of

\footnotetext{
1 Source: UNCTAD database 2018 (Gross domestic product: Total and per capita, growth rates, annual, 1970-2016).

Source: Pordata - 2019.

Source: UNCTAD database 2018 (Balance of payments, Current account balance, annual, 1980-2016).

Source: Pordata - 2019.
} 
external accounts, such as the goods and services account that also substantially improved its balance, or the financial balance; Silva, 2019: 72-3) was one of the main transformations of the Portuguese economy in the period under analysis. However, only the future can tell us if this is a strategic turning point leading to a consistent reduction in the importance of the traditional external constraints of the Portuguese economy. On the other hand, this process led to an increase in the internationalization of Portuguese companies induced by cyclical factors such as the lack of internal stimuli, in particular subsequent to the strong fall in domestic demand in the years 2011-2013, corresponding to $-5.5 \%,-7.3 \%,-2.5 \%$, respectively in terms of homologous change (Table 1 ), and the lack of credit that has lately affected the companies, with emphasis on the Small and Medium Sized Enterprises (SMEs) ${ }^{5}$. In this regard, it was highlighted how "the estimates on the extensive and intensive margin suggest that a significant fraction of Portuguese SMEs was affected by financing restrictions. The results also suggest that smaller and younger companies were the most affected" (Farinha and Félix, 2014: 16).

Table 1 - Portuguese Economic Indicators 2010-2018: annual change in domestic demand and exports

\begin{tabular}{|l|c|c|c|c|c|c|c|c|c|}
\hline \multicolumn{1}{|c|}{ Years } & $\mathbf{2 0 1 0}$ & $\mathbf{2 0 1 1}$ & $\mathbf{2 0 1 2}$ & $\mathbf{2 0 1 3}$ & $\mathbf{2 0 1 4}$ & $\mathbf{2 0 1 5}$ & $\mathbf{2 0 1 6}$ & $\mathbf{2 0 1 7}$ & $\mathbf{2 0 1 8}$ \\
\hline GDP (\%) & 1.9 & -1.3 & -4 & -1.6 & 0.9 & 1.8 & 1.9 & 2.8 & 2.1 \\
\hline Contribution of domestic demand to GDP & 0.4 & -2.9 & -7.6 & -2.5 & 0.3 & 1.1 & 0.9 & 1.3 & 1.3 \\
\hline Contribution of exports to GDP & 1.5 & 1.7 & 3.6 & 0.9 & 0.6 & 0.6 & 0.9 & 1.5 & 0.8 \\
\hline Domestic demand annual change (\%) & 1.9 & -5.5 & -7.3 & -2.5 & 2.2 & 2.7 & 2 & 3 & 2.8 \\
\hline Exports (weight in GDP in \%) & 30.1 & 35 & 38.2 & 40.3 & 40.9 & 41.2 & 40.7 & 43.3 (prov.) & 44.3 (prov.) \\
\hline
\end{tabular}

Source: Banco de Portugal Spring Economic Bulletin, years 2010-2018 and Pordata, handled by the authors themselves.

Bearing in mind the objectives of this article, starting from what was previously mentioned, it is necessary to go further in the study of the internationalization of the Portuguese economy and firms, focusing on the case of SMEs, which are a fundamental pillar of the Portuguese enterprise structure (Table 2). Without wishing to underestimate the role and potential of large companies or the diversity within SMEs, it is important to emphasize that internationalization has a great impact on the economic performance of these companies, namely in the introduction of new products and services in the sectors where they operate, as well as internationalized SMEs are more likely to internalize active innovation processes, compared to those that only operate in the domestic market (European Commission, 2010).

Table 2 - Structure of SMEs and Large Companies in the Portuguese Non-financial Sector

\begin{tabular}{|l|c|c|c|c|c|c|}
\hline & Number of Enterprises & $\%$ & Workers (Nr.) & \% & GVA (millions $\boldsymbol{\epsilon}$ ) & $\%$ \\
\hline SME & 1195064 & $99.9 \%$ & 2957309 & $79.8 \%$ & 54265 & $63.5 \%$ \\
\hline Big Enterprises & 1038 & $0.1 \%$ & 747431 & $20.2 \%$ & 31145 & $36.5 \%$ \\
\hline Total & 1196102 & & 3704740 & & 85410 & \\
\hline
\end{tabular}

Source: INE - Business statistics 2016 and treated by the authors themselves.

This work also aims to enlarge the research that has been carried out on the internationalization of Portuguese companies. In particular, we analyze here its orientation towards Latin American countries (focusing on the case of Ibero-American

5 We consider SMEs according to the European definition included in the Commission's recommendation 2003/361, which considers companies with less than 250 employees, a turnover of less than 50 million euros, a total balance sheet of less than 43 million euros; for a more detailed overview of the importance of SMEs in Portugal, see Silva and Simões, 2012: 824. 
countries), ${ }^{6}$ not only because it is a close space in linguistic and historical terms to Portugal, but also because there was an increase in the economic potential of this region since the beginning of the century, opening up new opportunities for business. Consequently, and although Latin American countries are far from homogeneous (Graph 1), these markets may be important for Portuguese companies, especially SMEs, and in general for the Portuguese economy in search for a greater diversification of its external relations.

Graph 1- Latin American Countries: Growth trends, 2009-2017 (Rate of year-on-year change in quarterly GDP between the 1st trimester 2009 and the 1st trimester 2017)

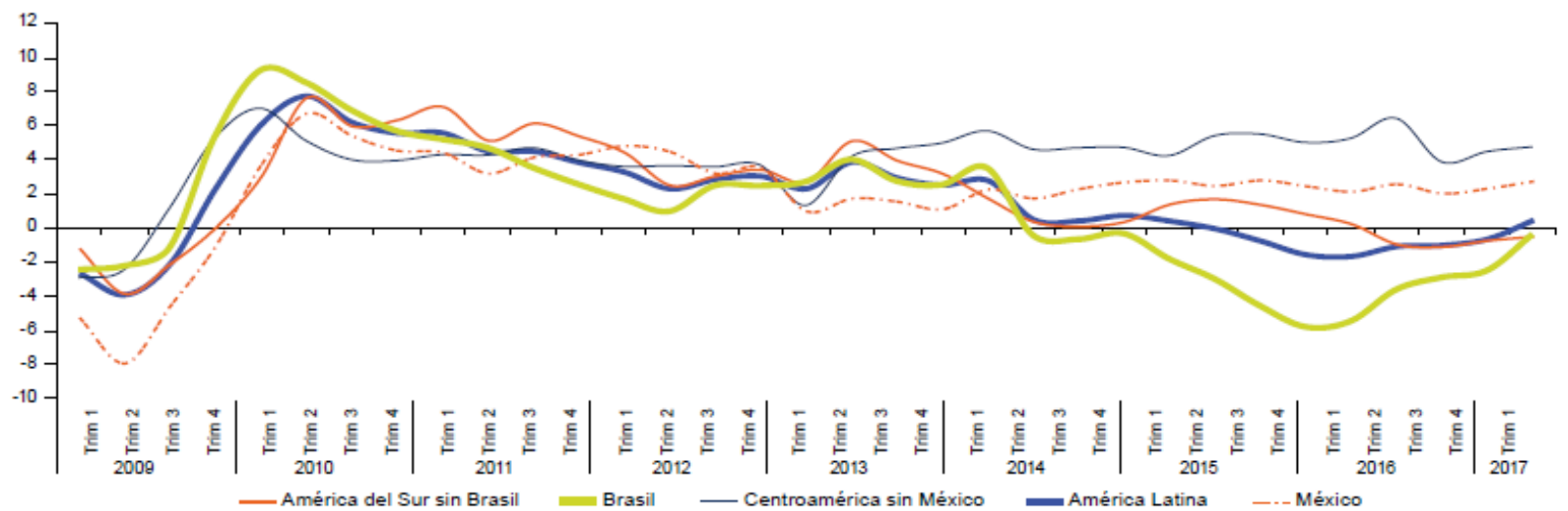

Source: CEPAL - Panorama Económico y Social de la Comunidad de Estados Latinoamericanos y Caribeños, 2017.

We thus seek to bring a new angle to the research on the internationalization of Portuguese SMEs, knowing that there is a scarcity of studies aiming at the analysis of the external economic relations of Portugal with the Latin American space (Silva, 2008), especially if we exclude Brazil, as well as its results are still little known. For the construction and validation of this study, we started from a set of questions: What are the main difficulties and requirements faced by companies when entering these markets? What internationalization process did they follow? What types of support did they have and how do they evaluate them? In terms of methodology, our work is based on the analysis of statistical series, but above all it is based on a direct survey carried out in 2014 to a significant group of Portuguese SMEs that have internationalized to Latin American markets, thus reinforcing the study of the transition process towards greater internationalization of the Portuguese economy through a relevant empirical basis.

Taking into account the features of the Portuguese economy up to the mid-2010s that we have presented above, particularly in terms of its external relations, and the objectives of this research, related to the internationalization of Portuguese companies, more accurately of SMEs to Latin America, several sections compose the article. In Section 2, we present a brief theoretical framework, exposing the main theories related to international trade and foreign direct investment (FDI), which are relevant in our context. In Section 3, we address the issue of the Ibero-American Space, considering these nations as a whole, and the integration frameworks in which they are involved, in

6 The issue will be detailed below, in Section 3. Considering that the problems related to the economic relations between Portugal and Spain have a very different context compared to that of American counterparts, accordingly, Spain will not be considered for the purposes of the central theme of this work, therefore, we will only address its case, in the context of the Iberian integration process in the European Community, and within the subsequent steps that were taken with a view to Ibero-American integration, insofar as these processes (economic integration) are relevant in the context of relations between Portugal and Latin American countries. 
particular that of the European Union for Portugal and Spain, an important vector, since it regulates a large part of the transactions under study. Section 4 is essential within the scope of this article, as it presents the survey carried out on Portuguese SMEs in their internationalization to Latin America, refers to the methodology that was followed, shows the results that were achieved, commenting on them and extracting a first set of conclusions about the process. Finally, Section 5 summarizes the main conclusions and raises some issues for further research.

\section{Theoretical Framework}

Considering the importance that internationalization processes have assumed in recent decades for most economies, it is necessary to present the theories that explain them, in particular with regard to its most significant flows and of greatest impact: international trade and foreign direct investment. This is what we do now, in an abbreviated manner and focusing on the essential.

Basically, according to the main theories on trade, the internationalization of economies goes through a process that leads to their specialization in certain products, based on the advantages that the country has, creating conditions for the exchange between commercial partners, through a greater efficiency that leads to an increase in output (with the same level of resources) to be shared. This approach was central to the classical authors of economic science, namely Adam Smith in his work Wealth of Nations (1776) whose lens used what would become known as the Theory of Absolute Advantages. According to Smith, countries should specialize according to their lower cost production (measured by labor cost, the only factor of production considered by these authors). However, considering two countries, this theory states that if one of them had lower costs in all relevant productions, it would have no interest in doing trade with the other and there would be no international specialization. David Ricardo will overcome this limitation in his reference work Principles of Political Economy and Taxation (1817), through the Theory of Comparative Advantages, which reformulates the question in other terms justifying trade even if one of the countries had all the absolute cost advantages in the production of goods. Rather, countries should specialize in products that have the lowest relative (and not absolute) cost, focusing on what they did most efficiently and opening up a wider space for international trade based on specialization with mutual benefits for the parties involved. Later, John Stuart Mill completed the contribution of the classical authors, drawing attention to the Law of Reciprocal Demand, that is, the exchange ratio is dependent on the reciprocal strength of the demands of each country in each product.

Although it is not the aim of this article to analyze the issue in depth, naturally, the positions of the classical authors have been subject to much criticism over the past two centuries; for example, specializing in one or another type of goods can have completely different consequences in the long run (for illustrative purposes, see that certain products correspond to a logic of increasing returns while others are in a decreasing returns drive, that is, in the long run the specialization process led to its ultimate consequences, may produce completely different results, i.e., unequal, as it was stressed by many authors, such as Reinert, 2007). In any case, classical theories remained a major benchmark for the internationalization process, both in terms of analysis and economic policy, although many of its initial assumptions have also been relaxed and/or changed.

On the path opened by the classical authors, one of the main developments was the emergence of the neoclassical theory of international trade during the first half of the $X X$ century, well exemplified by the Heckscher-Ohlin Theorem, which later had several extensions. These authors gave up one of the basic classical hypotheses, considering two factors of production, capital and labor, explaining the international specialization by the endowment of each country in these factors. In the case of a greater abundance of one factor (for example labor) relative to the other, the country should specialize in goods 
intensive in that factor, insofar as, having a cost advantage determined by its abundance, it was competitive (Santos, 2014).

Obviously, it is not our intention to present here in detail the development of these theories and all the reformulations and critiques they have originated (which still prevail in most international economics textbooks), but to show how the theories of internationalization of economies and companies follow certain rules and principles, which are essential for their good understanding. The same is also true for the case of foreign direct investment, which has gained much prominence in recent decades. Theories about capital movements, including FDI, developed later, as the classical authors postulated the international immobility of this factor. This premise was accepted for a long time, although this did not correspond entirely to the observed facts, even in the most remote times. Thus, it was only since the $60 \mathrm{~s}$ and $70 \mathrm{~s}$ of the last century that the theories on international capital movements emerged in a clear and autonomous way and proved to be adherent to the flows actually registered (which are in fact very diverse in nature from the financial ones to loans and direct investment). Within the scope of our research and given its importance for a sustainable internationalization process of companies, we will focus on two theories about FDI: the OLI (or Eclectic) Paradigm formulated by John Dunning and the contribution of the Nordic School of Business.

The OLI Paradigm is a model developed by John Dunning during the 1970 s, having been the subject of constant reflection by the author between the 1970s and the beginning of the XXI century (Dunning, 2000, 2001), which led to important adjustments and clarifications. The term Eclectic comes from the fact that this Paradigm is based in a combined manner on the three main areas in which FDI can be envisaged: the ownership advantages (Ownership Advantages - O) that already exist in companies, or that may be enhanced in their international expansion; the localization advantages (Localization Advantages - L) that countries or international markets can offer with respect to moving assets (for example, advantages arising from human or natural resources they have); and the internalization advantages (Internalization Advantages - I), that correspond to a trend of companies that have specific ownership advantages with the possibility of combining the assets they have in different foreign markets, without going directly through the market. Despite its eclecticism, in the author's view, this paradigm has some limitations, firstly its focus is on multinational companies, and secondly because the paradigm is limited to the interdependence of its OLI variables (Santos, 2014).

In this sense, there is another theoretical approach relevant to our study, especially with regard to the internationalization of SMEs. The Nordic School of Business or Uppsala School that sought to model the internationalization process of Swedish companies in the 1970 s, concluding that it is based more on a gradual sequence (Johanson and Vahlne, 1977, 1990; Johanson and Wiedersheim-Paul, 1975). Thus, the internationalization strategy of companies may have more or less steps, including "leaps" in their more likely sequence during the internationalization process (Silva, 2002a: 61), recognizing, however, that the main phases are: export, export agents, sales subsidiary, and production subsidiary (Johanson and Vahlne 1990; Santos, 2014). According to this model, in the initial stage of the internationalization process, basically characterized by exports, companies tend to do business with countries or markets with a shorter "psychic distance ${ }^{\prime 7}$. In the most advanced stages of the internationalization process, especially in the installation of a production branch, psychic distance is no longer such a determining factor in companies' FDI strategy, rather, factors such as the size of the market, or its specificities, with regard to the perceived attractiveness for FDI, which may be associated

The concept of psychic distance was developed by Vahlne and Wiedersheim-Paul in 1973, in a work in their original language and later developed in other works such as in Hállen and Wiedersheim-Paul (1979). It is the sum of all factors (language, culture, qualifications, political systems, history, corporate culture) that can cause entropy in the communication, circulation and analysis of information between countries, markets and companies, as there are deeper differences between the country of origin and the country receiving the FDI. 
with factors such as customs tariffs, insertion in large economic areas, transportation costs, or domestic purchasing power (Johanson and Vahlne, 1977, 1990; Johanson and Wiedersheim-Paul, 1975).

Regarding SMEs, and in contrast to the critique that was previously addressed to the OLI Paradigm (designed with big companies in mind, with vast resources, for example, with property advantages that allow important gains in imperfect competition, or with internalization advantages through their many branches around the world), the model of the Nordic Business School is based on a theory that supports an explanatory model, which takes into account the size and resources of SMEs, especially in the initial process of their internationalization (Johanson and Vahlne, 1990).

More recently Johanson and Vahlne (2009) reflecting on the Uppsala School model, highlighted the role of the Networks in the internationalization process, where companies within the network benefit from a privileged context of communication and interconnection, creating relationships in which learning and knowledge, business opportunities, and synergies in the internationalization process, are shared (Raposo et al., 2004). Taken as a whole, Johanson and Vahlne (2009) point us to yet another gap to be filled in the initial model:

\begin{abstract}
When we built our original model, we were not aware of the importance of mutual commitment for internationalization. Now, our vision is that successful internationalization requires a reciprocal commitment between the company and its counterparts (Johanson \& Vahlne, 1990; Vahlne \& Johanson, 2002) (Johanson and Vahlne, 2009: 1414).
\end{abstract}

To conclude this section, it should also be noted that recent empirical work has contributed to clarify important theoretical issues related to the substance of our research, i.e., international economic relations between countries with some degree of cultural proximity in the broad sense. For example, gravitational models that initially sought to explain international trade and investment by factors of a physical nature such as geographical distance or else by the value of production, measured by the size of GDP (Cechella et al., 2009: Cechella et al., 2012), showed limitations leading to the conclusion that this type of influences is not as important today as it was in the past or was thought to be (Eichengreen and Irwin, 1998), while factors such as language and historical and institutional proximity have been gaining relevance having a role that should not be underestimated in any way (Silva, 2005; Costa, 2005, Cechella et al., 2014). In addition to other aspects, these considerations imply that the explanation of international flows must also take into account the contribution of other scientific areas, such as history, political science and international relations that study facts and dimensions that influence many economic ties and partnerships that are established on a global scale.

\title{
3. The Ibero-American Market
}

\subsection{The Socioeconomic nature}

The Ibero-American Space is an important cultural and economic space that brings together twenty-two states, nineteen on the American continent, being: Argentina, Bolivia, Brazil, Colombia, Costa Rica, Cuba, Chile, Ecuador, El Salvador, Guatemala, Honduras, Mexico, Nicaragua, Panama, Paraguay, Peru, Dominican Republic, Uruguay, and Venezuela, plus the three states that make up the Iberian Peninsula: Andorra, Spain, 
and Portugal, with two languages of Latin origin - Portuguese and Castilian ${ }^{8}$. The population of this space corresponds to about $9 \%$ of the world population, with an expected increase of approximately 90\% in the period from 1990 to 2030, from 477 million inhabitants to 748 million inhabitants. Being that it is subdivided into a ratio of $33.33 \%$ of the population of Portuguese-speaking countries, and $66.67 \%$ of the population of Spanish-speaking countries, with a trend towards a slight increase in the weight of the population of this language, because it has grown at a higher rate (Table $3)$.

Table 3 - Ibero-American Population *

\begin{tabular}{|c|c|c|c|c|c|c|c|c|c|}
\hline Years & 1990 & 1995 & 2000 & 2005 & 2010 & 2015 & 2020 & 2025 & 2030 \\
\hline Total Ibero-American population (thousands) & 477305 & 517790 & 556790 & 595009 & 632762 & 666003 & 697079 & 724788 & 748964 \\
\hline Percentage of the total population & $8.95 \%$ & $9.0 \%$ & $9.06 \%$ & $9.09 \%$ & $9.09 \%$ & $9.02 \%$ & $8.94 \%$ & $8.85 \%$ & $8.75 \%$ \\
\hline Portuguese-speaking countries as $\%$ of population & $33.37 \%$ & $33.30 \%$ & $33.34 \%$ & $33.19 \%$ & $32.78 \%$ & $32.49 \%$ & $32.15 \%$ & $31.79 \%$ & $31.42 \%$ \\
\hline Castilian-speaking countries in $\%$ of population & $66.63 \%$ & $66.70 \%$ & $66.66 \%$ & $66.81 \%$ & $67.22 \%$ & $67.51 \%$ & $67.85 \%$ & $68.21 \%$ & $68.58 \%$ \\
\hline
\end{tabular}

* It includes all the countries in this space, located on the Iberian Peninsula or on the American continent.

Source: UNCTADSTAT and handled by the authors themselves.

With regard to the economy of the Ibero-American Space, we can divide it into three economic regions: Iberian countries, South American countries, and Central American and Caribbean countries. The economic space as a whole showed a constant growth in GDP and GDPpc in the two decades of 1990 and 2000, with the respective global GDP growth of $34 \%$ and $33 \%$. In the decade that started in 2010 , however, there was a slowdown of GDP within this space, with a similar impact on GDPpc as well as a reduction of its share in terms of world output (Table 4).

Table 4 - Macroeconomic Data for the Ibero-American Space (GDP and GDPpc at constant 2010 prices)*

\begin{tabular}{|c|c|c|c|c|c|c|c|c|c|c|c|c|}
\hline Years & 1990 & 1995 & 2000 & 2005 & 2010 & 2011 & 2012 & 2013 & 2014 & 2015 & 2016 & 2017 \\
\hline Total GDP of the lbero-American space (Thousands of dollars) & 3827668 & 4392883 & 5132076 & 5863994 & 6831409 & 7043932 & 7147801 & 7280569 & 7359376 & 7386739 & 7339087 & 7433036 \\
\hline Growth rate (\%) & & $14.77 \%$ & $16.83 \%$ & $14.26 \%$ & $16.50 \%$ & $3.11 \%$ & $1.47 \%$ & $1.86 \%$ & $1.08 \%$ & $0.37 \%$ & $-0.65 \%$ & $1.28 \%$ \\
\hline Percentage in relation to World GDP & $10.06 \%$ & $10.40 \%$ & $10.25 \%$ & $10.07 \%$ & $10.33 \%$ & $10.32 \%$ & $10.22 \%$ & $10.15 \%$ & $9.98 \%$ & $9.74 \%$ & $9.45 \%$ & $9.29 \%$ \\
\hline GDP pc of the lbero-American space (dollars) & 7238 & 7631 & 8614 & 8907 & 9508 & 9690 & 9809 & 9948 & 10109 & 10274 & 10403 & 10604 \\
\hline GDP pc ratio of lbero-American / World & 1.014 & 1.039 & 1.057 & 1.070 & 1.049 & 1.043 & 1.039 & 1.043 & 1.044 & 1.042 & 1.032 & 1.024 \\
\hline
\end{tabular}

* Data include all the countries in this space, located in the Iberian Peninsula or the American continent.

Source: UNCTADSTAT and handled by the authors themselves.

\subsection{Ibero-American market analysis}

The nature of the market in the three regions that make up the area is somewhat different, especially between the American countries and the states that make up the Iberian Peninsula. For the former, we can identify that there is a greater emphasis on primary and extraction activities, as well as on construction, which reveals the relative gap in the development of these regions, where the need to build infrastructure to support economic activities is evident. Comparing with Portugal, we also note that in the American Regions there is a much lower weight of manufacturing industries. These are some of the conclusions that we can draw through a careful reading of Graphs 2 to 4 .

8 As stated on the website of the Ibero-American General Secretariat, https://mandatos.segib.org/pt-br [Consulted on 18/02/2019]. 
Graph 2 - Distribution of Portuguese Economy Activities by Product - Year 2016

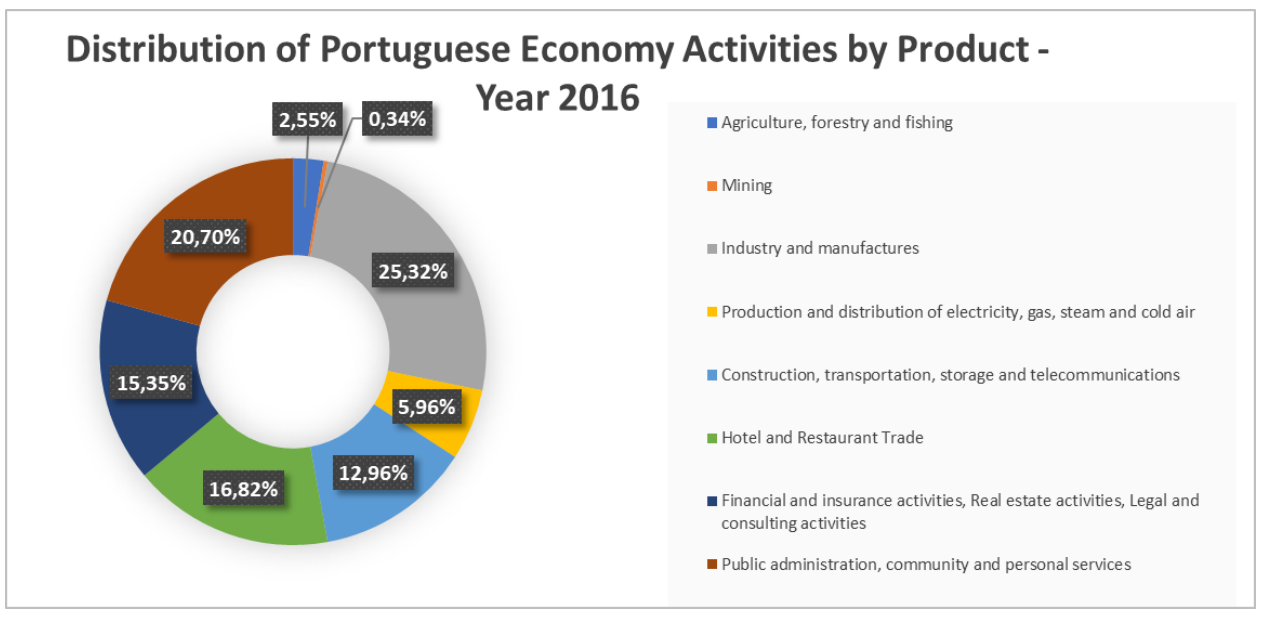

Source: PORDATA - 2019. Edited by the authors.

Graph 3 - Distribution of Economic Activities in Latin American countries by Product - Year 2017

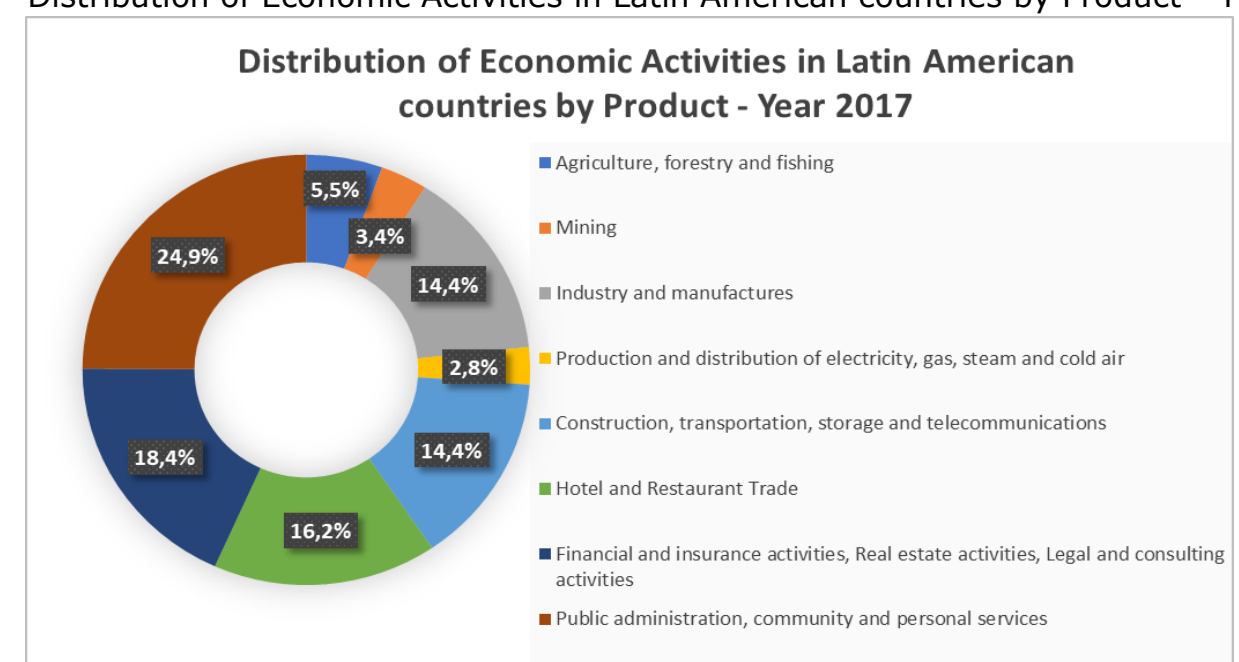

Source: ECLAC - Latin American and Caribbean Yearbook, 2018. Edited by the authors.

Graph 4 - Distribution of Economic Activities in Caribbean Countries by Product - Year 2018

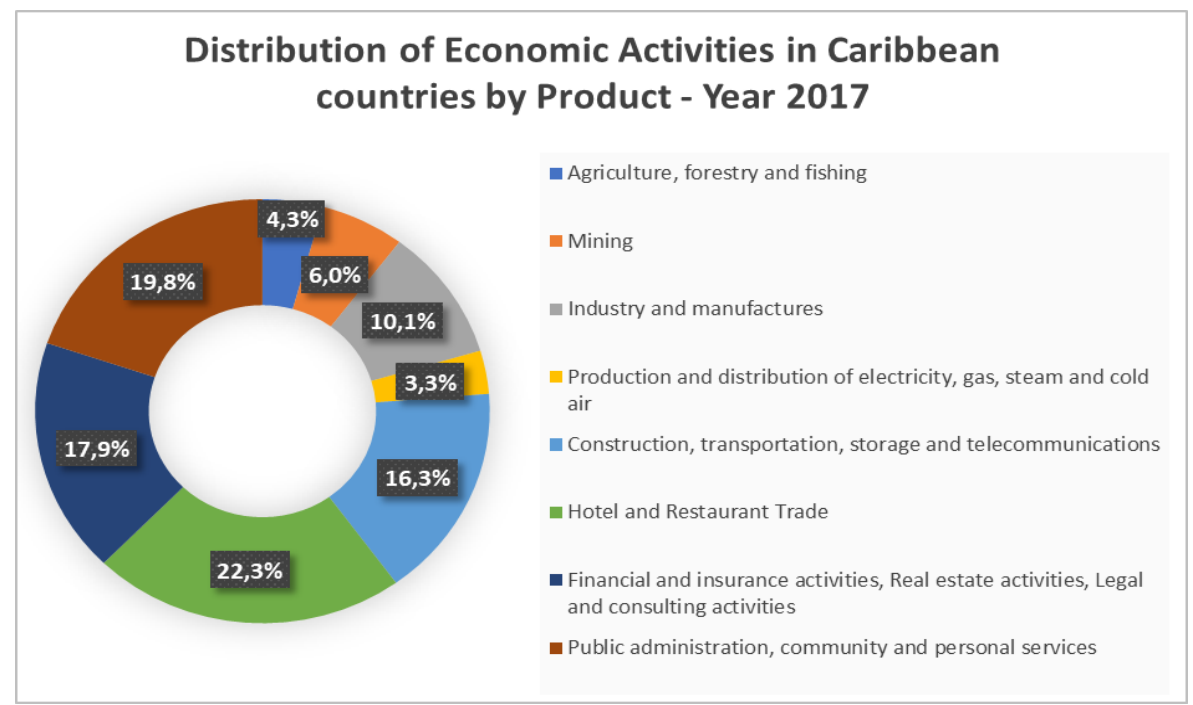

Source: ECLAC - Latin American and Caribbean Yearbook, 2018. Edited by the authors. 
According to what we referred to in the theoretical part, and analyzing the distribution of production in the countries of Latin America and the Caribbean it can be concluded that they have a strong endowment in natural resources, so it is not surprising that their exports have a significant weight of products associated with raw materials, which makes them very sensitive to fluctuations in their prices in international markets. For example, the fall in the price of commodities in the mid-2010s was one of the factors that most contributed to the poor economic performance in several countries in the region, compared to the first decade of the XXI century.

\subsection{International Cooperation in the Ibero-American Space}

The integration process of the Ibero-American Space has several levels, since it is subdivided by the set of international cooperation relations between states. Portugal and Spain are on a higher level of integration, since they belong to the European Community (since 1986), the European Union (since 1992 with the Maastricht Treaty), and the Monetary Union (since 1999), making them partners for excellence with regard to most of the international community policies, constituting in particular an important factor for the development of the process of rapprochement between the European Union and the Latin American countries (Trein and Guerra Cavalcanti, 2007). Indeed, the strong links of the two Iberian countries to Latin America are one of the aspects that most value their position in the European context. It is not surprising that the I Ibero-American Summit ${ }^{9}$ was held in Guadalajara, Mexico in 1991, taking the first step in the process of integrating the Ibero-American Space in its entirety, just a few years after Portugal and Spain joined the European Community.

For its part, the Latin American Market is distinct from the point of view of the cooperation and integration of the Regions of Central America and the Caribbean, and of South America. We will now highlight the two most relevant cases from this point of view. In 1991, the Mercosur Treaty was signed, originally by four countries in South America: Argentina, Brazil, Paraguay and Uruguay and later in 2012 Venezuela also joined, appearing with the objective of promoting an integration logic, aiming at an enlarged and deeper common market, that serves as a platform for the participation of these states in the global market under more favorable conditions (Diz and Luquini, 2011; Kegel e Amal, 2013). More recently in 2012, the Pacific Alliance was created, "composed by Colombia, Peru, Chile and Mexico, which brings together countries with very close international patterns, guided by trade liberalization and the signing of free trade agreements with developed and developing countries" (Bressan and Luciano, 2018: 74).

Regarding institutional relations between the European Union and Latin America, reference should also be made to the "signing of the Interregional Agreement between the EU and Mercosur, with the aim of covering trade and economic issues, cooperation on integration and other areas of mutual interest, in order to strengthen relations between the two regions" (Santos, 2014: 24) ${ }^{10}$. However, and according to Diz and Luquini (2011), there has not been a great evolution in the integration of these two spaces, and over the past two decades there were some advances, but numerous obstacles to the process were also raised. However, and more recently, the European Union and Mercosur signed a new agreement on 28 June 2019, which could lead to deeper economic integration between these two spaces, that is, as reported, "today they reached a political agreement with a view to an ambitious, balanced and comprehensive trade

9 XXVI Summits (Cumbres) have been held so far, and the Ibero-American Cooperation Secretariat was established at the IX Summit in Havana, Cuba in 1999 (SECIB). Organ that stipulates the true institutionality of the Ibero-American system (Freres, 2005).

10 Interregional Agreement signed in 1995, however, it was only approved by the Council of European Ministers in 1999. 
agreement. The new commercial framework - which is part of a wider association agreement between the two regions - will consolidate a strategic partnership at the political and economic level and create important sustainable growth opportunities for both parties"11. Regardless of this step forward, it should be remembered that the process leading to a greater degree of free trade between the EU and Mercosur was launched in the 1990 s and the results to date have been scant, ${ }^{12}$ so the new agreement must be monitored with caution, especially since important doubts persist about its implementation from both sides.

\subsection{Portugal and the Latin American market}

It is also necessary to make a brief analysis of the economic relations between Portugal and the Latin American countries.

As we have already mentioned, exports have recently been determinant for the development of the Portuguese economy, the country has been experiencing a consolidated growth where we can see that the weight of exports in relation to Portuguese GDP grew significantly. Table 1 showed that in 2010, the weight of exports (goods and services) in GDP was $30.1 \%$, and that, in 2018, it was expected to reach a value of $43.3 \%$ of GDP, which corresponds to an effective transformation of the Portuguese tradable economy. With regard to the exports of goods (those that have the greatest weight in the group), they present some diversification of the products supplied by the industry, since there is not an excessive concentration in one or two main products. Thus, we can identify the main products exported by Portugal in 2017, as a percentage of total exports: Refined Petroleum Products $(4.7 \%)$, Motor Vehicles $(4.2 \%)$, Automotive Components $(4.1 \%)$, Leather Shoes $(3.5 \%)$, Uncoated Paper $(1.9 \%)$, Tire Rubber $(1.8 \%)$, Packaged Medicines (1.7\%), Seats (1.7\%), Knitted Sweaters (1.4\%), Wine $(1.4 \%)$. These ten products are equivalent to about $26.4 \%$ of total Portuguese exports. ${ }^{13}$

Looking now at exports to the Latin American market, we find that this space does not have a large weight in the total of Portuguese exports, having varied between $3.1 \%$ and $4 \%$ in the last decade (Graph 5). On the other hand, and according to Table 5, in the region, the main destination countries for Portuguese exports are: Brazil with a weight between $1.26 \%$ and $1.73 \%$; Mexico between $0.65 \%$ and $0.97 \%$; Argentina between $0.15 \%$ and $0.36 \%$; Chile between $0.18 \%$ and $0.27 \%$; Colombia, which grew in this decade from $0.06 \%$ in 2010 to $0.18 \%$ in 2016; finally, Venezuela, a country where a vast community of the Portuguese diaspora lives, but that, in recent years, has been going through a deep economic crisis, with direct repercussions on Portuguese exports. Indeed, we can see that Venezuela absorbed $0.64 \%$ of national exports in 2013 , and that it does not go beyond $0.02 \%$ in 2017 . Despite the fact that the Ibero-American market does not have a very significant weight in Portuguese exports, it should not be neglected, quite the opposite, as it is a market that allows an expansion of Portuguese foreign trade. Due to its Latin linguistic and cultural proximity, including migration movements, whose influence we have referred to in the theoretical part, but also to the size and potential of the market itself, both factors put Latin American countries as an important space in future Portuguese internationalization strategies.

11 https://ec.europa.eu/commission/presscorner/detail/pt/ip 193396 [Consulted on 12/07/2019]

12 For an analysis of the initial phase of this process and the main problems that arose since its very beginning, as well as its permanence and difficult resolution, see for a broader development chap. 3 of Silva, 2002b: 161-202.

13 According to the data collected from Observatory of Economic Complexity (OEC) https://atlas.media.mit.edu/pt/profile/country/prt/ [Consulted on 08/04/2019]. 
Graph 5 - Weight of the Ibero-American Space in Total Portuguese Exports from 2010 to 2017

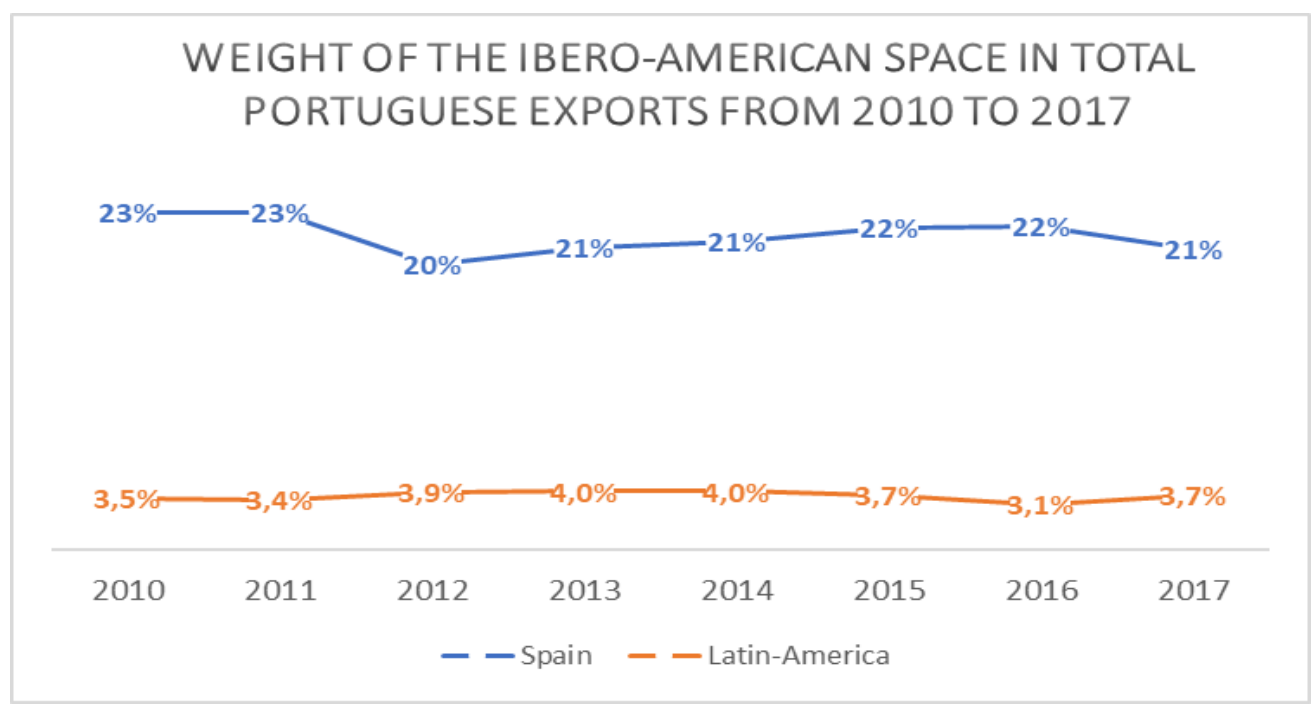

Source: Observatory of Economic Complexity (OEC) - 2019. Edited by the authors.

In this regard, it is worth mentioning the example of Spain, which is currently the main foreign market of Portugal with a share from $1 / 4$ to $1 / 5$ of national exports (Graph 5) because in the last 50 years this bilateral trade witnessed a radical transformation. In 1968 , Spain represented no more than $1.5 \%$ of Portuguese exports, only having a significant weight after the EEC membership, in 1986, in the year of 1988 the neighboring country reached a weight of $11.2 \%$ and in 1991 of $14.9 \%$ (Silva, 1993: 182). This example demonstrates that economic relations between states are not static, and that often depend on internationalization strategies and institutional relations between countries, hence we consider that just like the Spanish case in the last half century, the Ibero-American market may come to play an important role in future Portuguese internationalization strategies, with important effects in terms of the orientation of companies and their preparation.

Table 5 - Portuguese Exports to the Latin American Space (as a percentage of total Portuguese exports).

\begin{tabular}{|l|c|c|c|c|c|c|c|c|}
\hline & 2010 & 2011 & 2012 & 2013 & 2014 & 2015 & 2016 & 2017 \\
\hline Spain & $23 \%$ & $23 \%$ & $20 \%$ & $21 \%$ & $21 \%$ & $22 \%$ & $22 \%$ & $21 \%$ \\
\hline Latin-America & $3.5 \%$ & $3.4 \%$ & $3.9 \%$ & $4 \%$ & $4 \%$ & $3.7 \%$ & $3.1 \%$ & $3.7 \%$ \\
\hline Argentina & $0.20 \%$ & $0.15 \%$ & $0.19 \%$ & $0.36 \%$ & $0.18 \%$ & $0.32 \%$ & $0.16 \%$ & $0.23 \%$ \\
\hline Bolivia & $0.004 \%$ & $0.01 \%$ & $0.01 \%$ & $0.01 \%$ & $0.02 \%$ & $0.03 \%$ & $0.01 \%$ & $0.02 \%$ \\
\hline Brazil & $1.26 \%$ & $1.46 \%$ & $1.7 \%$ & $1.69 \%$ & $1.73 \%$ & $1.45 \%$ & $1.18 \%$ & $1.68 \%$ \\
\hline Chile & $0.29 \%$ & $0.21 \%$ & $0.22 \%$ & $0.18 \%$ & $0.23 \%$ & $0.23 \%$ & $0.25 \%$ & $0.26 \%$ \\
\hline Colombia & $0.06 \%$ & $0.09 \%$ & $0.13 \%$ & $0.10 \%$ & $0.16 \%$ & $0.16 \%$ & $0.18 \%$ & $0.12 \%$ \\
\hline Costa Rica & $0.03 \%$ & $0.02 \%$ & $0.02 \%$ & $0.02 \%$ & $0.02 \%$ & $0.03 \%$ & $0.03 \%$ & $0.01 \%$ \\
\hline Cuba & $0.05 \%$ & $0.05 \%$ & $0.10 \%$ & $0.07 \%$ & $0.07 \%$ & $0.09 \%$ & $0.09 \%$ & $0.08 \%$ \\
\hline Dominican Republic & $0.02 \%$ & $0.02 \%$ & $0.03 \%$ & $0.03 \%$ & $0.03 \%$ & $0.04 \%$ & $0.04 \%$ & $0.05 \%$ \\
\hline Ecuador & $0.03 \%$ & $0.03 \%$ & $0.03 \%$ & $0.07 \%$ & $0.05 \%$ & $0.1 \%$ & $0.07 \%$ & $0.04 \%$ \\
\hline El Salvador & $0.02 \%$ & $0.02 \%$ & $0.02 \%$ & $0.02 \%$ & $0.03 \%$ & $0.03 \%$ & $0.02 \%$ & $0.03 \%$ \\
\hline Guatemala & $0.01 \%$ & $0.01 \%$ & $0.01 \%$ & $0.02 \%$ & $0.02 \%$ & $0.04 \%$ & $0.03 \%$ & $0.03 \%$ \\
\hline Honduras & $0.01 \%$ & $0.01 \%$ & $0.01 \%$ & $0.01 \%$ & $0.01 \%$ & $0.01 \%$ & $0.01 \%$ & $0.01 \%$ \\
\hline Mexico & $0.97 \%$ & $0.88 \%$ & $0.64 \%$ & $0.61 \%$ & $0.75 \%$ & $0.70 \%$ & $0.71 \%$ & $0.94 \%$ \\
\hline Nicaragua & $0.002 \%$ & $0.002 \%$ & $0.005 \%$ & $0.004 \%$ & $0.004 \%$ & $0.005 \%$ & $0.004 \%$ & $0.01 \%$ \\
\hline Panama & $0.018 \%$ & $0.02 \%$ & $0.04 \%$ & $0.03 \%$ & $0.04 \%$ & $0.04 \%$ & $0.04 \%$ & $0.04 \%$ \\
\hline
\end{tabular}


JANUS.NET, e-journal of International Relations e-ISSN: 1647-7251

Vol. 11, No. 1 (May-October 2020), pp.77-97

The importance of Latin American space in the internationalization of Portuguese SMES

André Brás-dos-Santos; Joaquim Ramos Silva

\begin{tabular}{|l|c|c|c|c|c|c|c|c|} 
Paraguay & $0.005 \%$ & $0.04 \%$ & $0.05 \%$ & $0.06 \%$ & $0.046 \%$ & $0.03 \%$ & $0.03 \%$ & $0.04 \%$ \\
\hline Peru & $0.06 \%$ & $0.06 \%$ & $0.08 \%$ & $0.08 \%$ & $0.08 \%$ & $0.1 \%$ & $0.08 \%$ & $0.08 \%$ \\
\hline Uruguay & $0.02 \%$ & $0.02 \%$ & $0.03 \%$ & $0.04 \%$ & $0.09 \%$ & $0.03 \%$ & $0.02 \%$ & $0.02 \%$ \\
\hline Venezuela & $0.44 \%$ & $0.30 \%$ & $0.59 \%$ & $0.64 \%$ & $0.44 \%$ & $0.27 \%$ & $0.15 \%$ & $0.02 \%$ \\
\hline
\end{tabular}

Source: Observatory of Economic Complexity (OEC) - 2019. Edited by the authors.

\section{Analysis of the Internationalization of Portuguese SMEs to the Latin American Space}

\subsection{The empirical survey and its methodology}

As part of this work, in June 2014, a survey was carried out on Portuguese SMEs, in order to characterize their internationalization process for Latin America, which results are presented and analyzed in this section. We started from a database of SMEs and exporters to Latin American countries of 5872 companies as the universe of the study. This total was reached by joining a list of excellence SMEs in the year 2013 from IAPMEI with 3920 companies, and a database of companies exporting to the Central and South American markets of AICEP with 1952 companies. In the development of the research, we also counted on the precious help of business associations that participated in the survey and disclosed it to their associates.

We obtained responses from 107 companies, corresponding to $1.8 \%$ of the universe's population, of which 50 questionnaires were validated within the parameters of the study ( $0.85 \%$ of the population), for being SMEs according to the criteria mentioned above and for being internationalized to Latin America.

The survey was divided into four categories of questions: I - Company data, II - Export profile of the SME, III - Outline of the international investment profile of the SME, IVOutline of the internationalization process and assessment of the institutional role. In preparing the inquiry, we took as a base the survey prepared by Simões (2010), and adapted to the study of SMEs by Silva and Simões (2012), which was complemented with new questions, aimed at obtaining data on the assessment of organizations, following the methodologies of Hill and Hill (2008) and Manheim et al. (2007). SPSS (version 22) was also used to perform tabulation, coding and analysis of information, based on a descriptive analysis of frequencies.

\subsection{Outline of the profile of SMEs and their internationalization}

Most of the companies that compose the sample come from 5 districts of the coast of Portugal (Porto, Aveiro, Lisbon, Leiria and Setúbal), which correspond to $76 \%$ of the total. Most of these companies are connected to the manufacturing industries, $64 \%$, and most companies have an equity capital over 100 thousand euros, $69.4 \%$. From the point of view of jobs, we identified that $88 \%$ of the SMEs surveyed have more than 10 workers. We could also observe that in the international activity, $70 \%$ of the companies are orientated to export, $16 \%$ export and make direct investment, and that $14 \%$ maintain another type of international activity, such as partnerships.

From the point of view of consolidating the internationalization of companies, the results of the survey show that two thirds have had international activity for more than ten years, i.e., 66\%. Regarding the importance of international activity in the invoicing of companies, we found that the weight was greater than $50 \%$ of the total in $40 \%$ of the sample, and between 25 to $50 \%$ of the total in $23 \%$ of the sample. Regarding the type of presence in the countries to which they export, through Table 6 , we can see that the most frequent way is the "direct approach to the customer" $(28 \%)$, followed by 'no presence' $(8 \%)$, the existence of an 'agent' $(8 \%)$, and a 'network of distributors" $(8 \%)$.

Table 6 - Types of External Presence 


\begin{tabular}{|c|c|c|c|}
\hline Types of Presence & Frequency & Percentage & $\begin{array}{l}\text { Cumulative } \\
\text { percentage }\end{array}$ \\
\hline Direct Customer Approach & 14 & $28 \%$ & $28 \%$ \\
\hline No presence & 4 & $8 \%$ & $36 \%$ \\
\hline Agent & 4 & $8 \%$ & $44 \%$ \\
\hline Distributor Network & 4 & $8 \%$ & $52 \%$ \\
\hline Agent and Direct Customer Approach & 3 & $6 \%$ & $58 \%$ \\
\hline Agent Network, Direct Customer Approach & 3 & $6 \%$ & $64 \%$ \\
\hline Distributor Network, Direct Customer Approach & 3 & $6 \%$ & $70 \%$ \\
\hline Agent, Agent Network, Distributor Network & 2 & $4 \%$ & $74 \%$ \\
\hline Subsidiary / Branch & 2 & $4 \%$ & $78 \%$ \\
\hline Agent, Agent Network, Direct Customer Approach & 1 & $2 \%$ & $80 \%$ \\
\hline $\begin{array}{l}\text { Agent, Agent Network, Distributor Network, Direct Customer } \\
\text { Approach }\end{array}$ & 1 & $2 \%$ & $82 \%$ \\
\hline Agent, Distributor Network & 1 & $2 \%$ & $84 \%$ \\
\hline Agent, Distributor Network, Direct Customer Approach & 1 & $2 \%$ & $86 \%$ \\
\hline Agent, Distributor Network, Subsidiary / Branch & 1 & $2 \%$ & $88 \%$ \\
\hline $\begin{array}{l}\text { Agent, Distributor Network, Subsidiary / Branch, Direct } \\
\text { Customer Approach }\end{array}$ & 1 & $2 \%$ & $90 \%$ \\
\hline Subsidiary / Branch, Direct Customer Approach & 1 & $2 \%$ & $92 \%$ \\
\hline Displaced service provision & 1 & $2 \%$ & $94 \%$ \\
\hline Agent Network & 1 & $2 \%$ & $96 \%$ \\
\hline $\begin{array}{l}\text { Agent Network, Distributor Network, Direct Customer } \\
\text { Approach }\end{array}$ & 1 & $2 \%$ & $98 \%$ \\
\hline Tourism & 1 & $2 \%$ & $100 \%$ \\
\hline Total & 50 & $100 \%$ & \\
\hline
\end{tabular}

Respecting the (export) activities that have already been carried out, it was found that the country most mentioned by companies was Brazil (31\% of the mentions), followed by Colombia (16\%), Mexico (12\%), Chile (10\%), Argentina $(7 \%)$, and Uruguay $(7 \%)$, and they still export irregularly to ten other countries and seven others are not even mentioned (Table 7). However, we found that $47 \%$ of the companies expressed interest in exporting in the future to Latin America, with special relevance to Colombia $(13 \%)$, Brazil (10\%) and Mexico (8\%) (Table 8 ).

Table 7 - Latin American Countries to which they Export?

\begin{tabular}{|c|c|c|c|c|c|c|c|c|}
\hline \multirow{2}{*}{ Country } & \multicolumn{2}{|c|}{ Total Mentions } & \multicolumn{2}{|c|}{ 1st Position } & \multicolumn{2}{c|}{ 2nd Position } & \multicolumn{2}{c|}{3 rd Position } \\
\cline { 2 - 10 } & Frequency & Percentage & Frequency & Percentage & Frequency & Percentage & Frequency & Percentage \\
\hline Brasil & 18 & $31 \%$ & 16 & $57 \%$ & 1 & $5 \%$ & 1 & $8 \%$ \\
\hline Colombia & 9 & $16 \%$ & 2 & $7 \%$ & 4 & $18 \%$ & 3 & $23 \%$ \\
\hline Mexico & 7 & $12 \%$ & 4 & $14 \%$ & 2 & $9 \%$ & 1 & $8 \%$ \\
\hline Chile & 6 & $10 \%$ & 4 & $14 \%$ & 1 & $5 \%$ & 1 & $8 \%$ \\
\hline Argentina & 4 & $7 \%$ & 1 & $4 \%$ & 2 & $9 \%$ & 1 & $8 \%$ \\
\hline Uruguay & 4 & $7 \%$ & 0 & $0 \%$ & 2 & $9 \%$ & 2 & $15 \%$ \\
\hline Honduras & 2 & $3 \%$ & 0 & $0 \%$ & 2 & $9 \%$ & 0 & $0 \%$ \\
\hline
\end{tabular}




\begin{tabular}{|c|c|c|c|c|c|c|c|c|}
\hline \multirow{2}{*}{ Country } & \multicolumn{2}{|c|}{ Total Mentions } & \multicolumn{2}{|c|}{ 1st Position } & \multicolumn{2}{|c|}{ 2nd Position } & \multicolumn{2}{|c|}{ 3rd Position } \\
\hline & Frequency & Percentage & Frequency & Percentage & Frequency & Percentage & Frequency & Percentage \\
\hline Peru & 2 & $3 \%$ & 0 & $0 \%$ & 1 & $5 \%$ & 1 & $8 \%$ \\
\hline Venezuela & 2 & $3 \%$ & 0 & $0 \%$ & 1 & $5 \%$ & 1 & $8 \%$ \\
\hline Costa Rica & 1 & $2 \%$ & 0 & $0 \%$ & 0 & $0 \%$ & 1 & $8 \%$ \\
\hline El Salvador & 1 & $2 \%$ & 1 & $4 \%$ & 0 & $0 \%$ & 0 & $0 \%$ \\
\hline Panama & 1 & $2 \%$ & 0 & $0 \%$ & 1 & $5 \%$ & 0 & $0 \%$ \\
\hline Paraguay & 1 & $2 \%$ & 0 & $0 \%$ & 0 & $0 \%$ & 1 & $8 \%$ \\
\hline Bolivia & 0 & $0 \%$ & 0 & $0 \%$ & 0 & $0 \%$ & 0 & $0 \%$ \\
\hline Cuba & 0 & $0 \%$ & 0 & $0 \%$ & 0 & $0 \%$ & 0 & $0 \%$ \\
\hline Ecuador & 0 & $0 \%$ & 0 & $0 \%$ & 0 & $0 \%$ & 0 & $0 \%$ \\
\hline Guatemala & 0 & $0 \%$ & 0 & $0 \%$ & 0 & $0 \%$ & 0 & $0 \%$ \\
\hline Haiti & 0 & $0 \%$ & 0 & $0 \%$ & 0 & $0 \%$ & 0 & $0 \%$ \\
\hline Nicaragua & 0 & $0 \%$ & 0 & $0 \%$ & 0 & $0 \%$ & 0 & $0 \%$ \\
\hline Dominican Republic & 0 & $0 \%$ & 0 & $0 \%$ & 0 & $0 \%$ & 0 & $0 \%$ \\
\hline Total Validated & 58 & $100 \%$ & 28 & $100 \%$ & 17 & $77 \%$ & 13 & $100 \%$ \\
\hline Others without indication & 15 & & 5 & $15 \%$ & 5 & $23 \%$ & 5 & $28 \%$ \\
\hline Total & 73 & & 33 & & 22 & & 18 & 0 \\
\hline
\end{tabular}

From the point of view of FDI, we note that its importance is reduced when compared to exports. In this sense, only $46 \%$ companies of the sample responded to the survey, but we were still able to identify the following: $65 \%$ of these companies hold FDI in Latin America for less than 2 years. The weight of these investments is still low as for $44 \%$ of respondents it is less than $5 \%$ of the billing, and with an accumulated value of $88 \%$ of companies where the weight is less than $25 \%$ of the billing. In terms of the countries receiving FDI, out of the 20 possible, it appears that only 8 countries attracted direct investment by the companies surveyed, where Brazil stands out (22\%), Argentina $(11 \%)$, Chile $(11 \%)$, Colombia $(11 \%)$, Costa Rica $(11 \%)$, Mexico $(11 \%)$, Panama $(11 \%)$, and Peru $(11 \%)$. In answering the question about the interest in future FDI movements, only $18 \%$ of possibilities for investments in Latin America were considered, with the remaining $82 \%$ in several countries on other continents.

Table 8 - Future Exports for Countries in the General Context

\begin{tabular}{|l|c|c|c|c|c|c|c|c|}
\hline \multirow{2}{*}{ Country } & \multicolumn{2}{|c|}{ Total Mentions } & \multicolumn{2}{c|}{ 1st Position } & \multicolumn{2}{c|}{ 2nd Position } & \multicolumn{2}{c|}{ 3rd Position } \\
\cline { 2 - 9 } & $\begin{array}{c}\text { Frequenc } \\
\mathrm{y}\end{array}$ & $\begin{array}{c}\text { Percentag } \\
\mathrm{e}\end{array}$ & $\begin{array}{c}\text { Frequenc } \\
\mathrm{y}\end{array}$ & $\begin{array}{c}\text { Percentag } \\
\mathrm{e}\end{array}$ & $\begin{array}{c}\text { Frequenc } \\
\mathrm{y}\end{array}$ & $\begin{array}{c}\text { Percentag } \\
\mathrm{e}\end{array}$ & $\begin{array}{c}\text { Percentag } \\
\mathrm{e}\end{array}$ & $\begin{array}{c}\text { Frequenc } \\
\mathrm{y}\end{array}$ \\
\hline Colombia & 8 & $13 \%$ & 3 & $13 \%$ & $\mathbf{3}$ & $\mathbf{1 4 \%}$ & $\mathbf{2}$ & $\mathbf{1 2 \%}$ \\
\hline Brazil & 6 & $10 \%$ & 5 & $21 \%$ & $\mathbf{1}$ & $\mathbf{5 \%}$ & $\mathbf{0}$ & $\mathbf{0} \%$ \\
\hline EUA & 5 & $8 \%$ & 3 & $13 \%$ & $\mathbf{1}$ & $\mathbf{5 \%}$ & $\mathbf{1}$ & $\mathbf{6 \%}$ \\
\hline Mexico & 5 & $8 \%$ & 0 & $0 \%$ & $\mathbf{3}$ & $\mathbf{1 4 \%}$ & $\mathbf{2}$ & $\mathbf{1 2 \%}$ \\
\hline Germany & 4 & $6 \%$ & 1 & $4 \%$ & $\mathbf{1}$ & $\mathbf{5 \%}$ & $\mathbf{2}$ & $\mathbf{1 2 \%}$ \\
\hline France & 3 & $5 \%$ & 0 & $0 \%$ & $\mathbf{3}$ & $\mathbf{1 4 \%}$ & $\mathbf{0}$ & $\mathbf{0} \%$ \\
\hline
\end{tabular}




\begin{tabular}{|c|c|c|c|c|c|c|c|c|}
\hline \multirow[b]{2}{*}{ Country } & \multicolumn{2}{|c|}{ Total Mentions } & \multicolumn{2}{|c|}{ 1st Position } & \multicolumn{2}{|c|}{ 2nd Position } & \multicolumn{2}{|c|}{ 3rd Position } \\
\hline & $\begin{array}{c}\text { Frequenc } \\
y\end{array}$ & $\begin{array}{c}\text { Percentag } \\
\mathrm{e}\end{array}$ & $\begin{array}{c}\text { Frequenc } \\
y\end{array}$ & $\begin{array}{c}\text { Percentag } \\
\mathrm{e}\end{array}$ & $\begin{array}{c}\text { Frequenc } \\
y\end{array}$ & $\begin{array}{c}\text { Percentag } \\
\mathrm{e}\end{array}$ & $\begin{array}{c}\text { Percentag } \\
\mathrm{e}\end{array}$ & $\begin{array}{c}\text { Frequenc } \\
y\end{array}$ \\
\hline Russia & 3 & $5 \%$ & 2 & $8 \%$ & 0 & $0 \%$ & 1 & $6 \%$ \\
\hline Angola & 2 & $3 \%$ & 1 & $4 \%$ & 1 & $5 \%$ & 0 & $0 \%$ \\
\hline Argentina & 2 & $3 \%$ & 1 & $4 \%$ & 0 & $0 \%$ & 1 & $6 \%$ \\
\hline Spain & 2 & $3 \%$ & 1 & $4 \%$ & 0 & $0 \%$ & 1 & $6 \%$ \\
\hline Panama & 2 & $3 \%$ & 1 & $4 \%$ & 1 & $5 \%$ & 0 & $0 \%$ \\
\hline Peru & 2 & $3 \%$ & 2 & $8 \%$ & 0 & $0 \%$ & 0 & $0 \%$ \\
\hline Poland & 2 & $3 \%$ & 0 & $0 \%$ & 1 & $5 \%$ & 1 & $6 \%$ \\
\hline Uruguay & 2 & $3 \%$ & 0 & $0 \%$ & 0 & $0 \%$ & 2 & $12 \%$ \\
\hline Saudi Arabia & 1 & $2 \%$ & 0 & $0 \%$ & 0 & $0 \%$ & 1 & $6 \%$ \\
\hline Belgium & 1 & $2 \%$ & 1 & $4 \%$ & 0 & $0 \%$ & 0 & $0 \%$ \\
\hline Belize & 1 & $2 \%$ & 0 & $0 \%$ & 1 & $5 \%$ & 0 & $0 \%$ \\
\hline Cape Verde & 1 & $2 \%$ & 1 & $4 \%$ & 0 & $0 \%$ & 0 & $0 \%$ \\
\hline Chile & 1 & $2 \%$ & 1 & $4 \%$ & 0 & $0 \%$ & 0 & $0 \%$ \\
\hline China & 1 & $2 \%$ & 0 & $0 \%$ & 1 & $5 \%$ & 0 & $0 \%$ \\
\hline South Korea & 1 & $2 \%$ & 0 & $0 \%$ & 1 & $5 \%$ & 0 & $0 \%$ \\
\hline Holand & 1 & $2 \%$ & 0 & $0 \%$ & 1 & $5 \%$ & 0 & $0 \%$ \\
\hline Indonesia & 1 & $2 \%$ & 0 & $0 \%$ & 0 & $0 \%$ & 1 & $6 \%$ \\
\hline Mozambique & 1 & $2 \%$ & 0 & $0 \%$ & 1 & $5 \%$ & 0 & $0 \%$ \\
\hline Norway & 1 & $2 \%$ & 0 & $0 \%$ & 0 & $0 \%$ & 1 & $6 \%$ \\
\hline Paraguay & 1 & $2 \%$ & 0 & $0 \%$ & 1 & $5 \%$ & 0 & $0 \%$ \\
\hline $\begin{array}{l}\text { United } \\
\text { Kingdom }\end{array}$ & 1 & $2 \%$ & 0 & $0 \%$ & 0 & $0 \%$ & 1 & $6 \%$ \\
\hline $\begin{array}{l}\text { Trinidad and } \\
\text { Tobago } \\
\end{array}$ & 1 & $2 \%$ & 1 & $4 \%$ & 0 & $0 \%$ & 0 & $0 \%$ \\
\hline Total & 62 & $100 \%$ & 24 & $100 \%$ & 21 & $100 \%$ & 17 & $100 \%$ \\
\hline $\begin{array}{l}\text { Latin } \\
\text { America }\end{array}$ & 29 & $47 \%$ & 13 & $54 \%$ & 9 & $43 \%$ & 7 & $41 \%$ \\
\hline $\begin{array}{l}\text { Other } \\
\text { Regions } \\
\end{array}$ & 33 & $53 \%$ & 11 & $46 \%$ & 12 & $57 \%$ & 10 & $59 \%$ \\
\hline
\end{tabular}

\subsection{Evaluation of the internationalization process and of the Portuguese Institutions that provide support}

Other relevant aspects for the internationalization process were also inquired, namely, what are the preferential forms of approach? What are their motives? What are the main obstacles to the process?

In terms of the preferential forms of approach, we identified that the main were «Displacement and direct contact » (74\%), and "Participation in fairs" (68\%). Regarding the motives, the most mentioned was "Increase in market share" $(82 \%)$, followed by "Notoriety and recognition in the national market" (30\%) and "Proximity to customers 》 $(28 \%)$ (Table 9 ). As for the obstacles identified in the process, the most relevant were the "Bureaucratic aspects" (64\%), as the second most frequent reason is the "Lack of incentives" (34\%), following in third position, simultaneously, the "Difficulty to obtain financing" and the "Lack of information" (22\%). A still relevant reason is the "Difficulty of access to institutions" (18\%). 
Table 9 - Main Motives for Internationalization?

\begin{tabular}{|l|c|c|c|c|c|}
\hline & \multicolumn{2}{|c|}{ Yes } & \multicolumn{2}{c|}{ No } & \\
\hline Motives for internationalization & Frequency & Percentage & Frequency & Percentage & Total \\
\hline Increased market share & 41 & $82 \%$ & 9 & $18 \%$ & 50 \\
\hline Notoriety and recognition in the national market & 15 & $30 \%$ & 35 & $70 \%$ & 50 \\
\hline Resource search & 7 & $14 \%$ & 43 & $86 \%$ & 50 \\
\hline Proximity to customers & 14 & $28 \%$ & 36 & $72 \%$ & 50 \\
\hline Fairer product valuation & 1 & $2 \%$ & 49 & $98 \%$ & 50 \\
\hline $\begin{array}{l}\text { Presence of a foreign community in the company's } \\
\text { region }\end{array}$ & 1 & $2 \%$ & 49 & $98 \%$ & 50 \\
\hline
\end{tabular}

The companies also carried out an evaluation of the main institutions that, in Portugal, give support to the internationalization process, from Bad (score 1) to Very Good (score 5 ), reserving a score of 3 for cases in which the company does not know or does not respond (position of indifference). The results are showed in Table 10: the Business/Commercial Associations are the highest scored (165 points), followed by Chambers of Commerce (152 points), IAPMEI (151 points), AICEP and Embassies/Consulates (140 points) and finally the Government (122 points). It is interesting to note that the responding firms value professional organizations such as business associations and chambers of commerce more than government bodies like AICEP, embassies/consulates (or the government), the latter being specifically formed or dedicated to the purpose.

Table 10 - Assessment of Institutions

\begin{tabular}{|c|c|c|c|c|c|c|}
\hline & AICEP & $\begin{array}{c}\text { Business/Trade } \\
\text { Associations }\end{array}$ & $\begin{array}{c}\text { Chambers of } \\
\text { Commerce }\end{array}$ & $\begin{array}{c}\text { Embassies/ } \\
\text { Consulates }\end{array}$ & Government & IAPMEI \\
\hline Bad (1) & 16 & 5 & 8 & 15 & 16 & 5 \\
\hline $\begin{array}{c}\text { Reasonable } \\
\text { (2) }\end{array}$ & 9 & 14 & 7 & 4 & 3 & 13 \\
\hline Good (4) & 13 & 11 & 7 & 4 & 3 & 12 \\
\hline $\begin{array}{c}\text { Very Good } \\
\text { (5) }\end{array}$ & 9 & 14 & 9 & 10 & 2 & 6 \\
\hline NS/NR (3) & 3 & 6 & 19 & 17 & 26 & 14 \\
\hline Score & $\mathbf{1 4 0}$ & $\mathbf{1 6 5}$ & $\mathbf{1 5 2}$ & $\mathbf{1 4 0}$ & $\mathbf{1 2 2}$ & $\mathbf{1 5 1}$ \\
\hline
\end{tabular}

Companies were also asked to suggest improvements to institutions. Of the 50 companies, $24 \%$ presented suggestions, which were summarized in Table 11.

Table 11 - Companies' Suggestions for Improving the process

\begin{tabular}{|l|}
\hline \multicolumn{1}{|c|}{ Summary of Suggestions } \\
\hline - Have an organized and credible dossier by markets with potential buyers so that \\
companies can make the contacts \\
\hline - Simplification of processes \\
\hline - \\
$\begin{array}{l}\text { Create representations manager, hold meetings with commercial attachés of } \\
\text { main purchasing manages want in companies with placement capacity, etc. Anyway, } \\
\text { anything that is not passive, reactionary and lethargic }\end{array}$ \\
\hline - $\begin{array}{l}\text { In some markets, more human and financial resources are needed for the local } \\
\text { support of companies }\end{array}$ \\
\hline - Ability to streamline processes and facilitate financing for SME projects \\
\hline
\end{tabular}


Finally, it was important to know what is the assessment that companies have of their own internationalization process, with only $6 \%$ of companies considering their experience as unsatisfactory (Table 12). The remaining companies, with the exception of $6 \%$ who have no opinion, considered the experience as positive, albeit to varying degrees. It should be noted that $42 \%$ rate the experience as good and $16 \%$ as very good.

Table 12 - How do you Evaluate your Internationalization Experience?

\begin{tabular}{|l|c|c|c|}
\hline & Frequency & Percentage & Cumulative percentage \\
\hline Unsatisfactory & 3 & $6 \%$ & $6 \%$ \\
\hline Satisfactory & 15 & $30 \%$ & $36 \%$ \\
\hline No opinion & 3 & $6 \%$ & $42 \%$ \\
\hline Good & 21 & $42 \%$ & $84 \%$ \\
\hline Very good & 8 & $16 \%$ & $100 \%$ \\
\hline Total & 50 & $100 \%$ & \\
\hline
\end{tabular}

\section{Conclusions}

This work aimed to carry out a political and economic analysis of the internationalization of the Portuguese economy to Latin America, focusing on the role of SMEs. We first saw how SMEs are a major driver of the Portuguese economy, both in terms of their number and the weight they have on gross added value and employment. The recessionary climate of the Portuguese economy in the early 2010s made the need for going international imperative. It is in this context that we intend to assess how Latin America, an area where there is linguistic and historical proximity (just remember the great migration currents of the past) prove to be an international destination of significance for Portuguese SMEs.

In the light of the internationalization theories that we focused on the theoretical section, we tried to identify the contours of this process, for example, testing the relevance of some concepts such as Psychic Distance. In this sense, it was possible to confirm that the Ibero-American market is not very expressive in the Portuguese exports as it did not correspond, on average of the years 2010-2017, to more than 3.7\% of the total. Even so, and from the responses to the survey, we found that the Latin American space should be taken seriously into consideration in the further steps towards internationalization of Portuguese SMEs, insofar it corresponds to $47 \%$ of the companies' intentions of exportation.

In an evaluation of the internationalization process of the SMEs that were surveyed, we can identify that they present a behavior somewhat similar to the process suggested by the Theory of the Nordic School of Business, i.e., a "gradual process of internationalization". Since most companies (about 70\%) are only dedicated to exports, and directly looking for the customer, we note a residual number of companies that have an "agent" or a "distribution network". With regard to FDI, we confirmed that few companies in the sample invested in Latin America, which for the case of SMEs should not be surprising given what we referred to above regarding their access to resources, namely financial and human resources. Considering another recent survey (Return on Ideas, 2018), it corroborates the analysis we presented earlier with regard to the internationalization of Portuguese SMEs into the world market. Actually, it states that direct exports to international customers $(61 \%)$, occasional exports $(25 \%)$, and exports through international agents $(16 \%)$ are the main forms of internationalization for Portuguese SMEs, while the use of FDI by these companies is residual, taking the form of its own branch and/or subsidiary ( $9 \%)$ and the presence abroad is rarely translated into production/manufacturing units $(1 \%)$. 
Despite the profile that has just been traced, it must be underlined that the importance of the international component in the turnover is quite significant for the companies that responded to the inquiry, showing that SMEs are in a process of gradual growth towards internationalization, eventually in the future making even medium and long term investments abroad, thus providing a continuous learning process. This will require the existence of international strategies and operations, which are necessary and correspond to needs, not even excluding investments. Taking into account this analysis, the selfassessment carried out by the companies seems consistent.

This work is far from being the end of the research carried out, it is rather another step in the investigation on the internationalization of the Portuguese economy and firms, to an important world region, where they can benefit from advantages, if their action is adequate and they know well the ground (of course, presumed cultural proximity is not enough per se). Thus, we have in mind the pursuit of this research, developing the theme of the internationalization of SMEs to Latin America, expanding the sample, and complementing it with case studies, which would allow to go beyond the limits that a survey carried out in a given year, although recent, necessarily has. Such an approach would lead to a more longitudinal view of the analyzed process, allowing stronger conclusions. Another issue raised by this research is that of an empirical study comparing in depth the Portuguese case, with the process of Spanish SMEs for the same economic space, assessing similarities and differences and their causes and implications.

\section{References}

Bressan, R. N., and Luciano, B. T. (2018). «A Comunidade Andina no século XXI: entre bolivarianos e a Aliança do Pacífico». Revista de Sociologia e Política, 26(65), 62 to 80.

Cechella, C., Dentinho, T., and Silva, J. R. (2012). «World centralities for political, demographic and market purposes». Letters in Spatial and Resource Sciences, Vol. 5, 2, July, 73 to 83 .

Cechella, C., Franco, G. H. B., Silva, J. R., and Dentinho, T. P. (2014). «New Dimensions of Brazilian Economy Internationalization: Portugal as a strategic location for EMBRAER's investments and their impact on the regional economy». Revista Portuguesa de Estudos Regionais, 35, 3 to 13.

Cechella, C., Silva J. R., and Dentinho, T. P. (2009). «Explaining trade and FDI relationships in a gravitational model». Studies in Regional Science, Vol. 39, 1, 41 to 52.

CEPAL (2018). Panorama Económico y Social de la Comunidad de Estados Latinoamericanos y Caribeños, 2017. Santiago: Comisión Económica para América Latina y el Caraíbas (CEPAL).

CEPAL (2019). Anuario Estadístico de América Latina y el Caraíbas, 2018. Santiago: Comisión Económica para América Latina y el Caraíbas (CEPAL).

Costa, C. G. (2005). A Cultura como Fator Dinamizador da Economia: Os Investimentos Portugueses no Brasil. Lisboa: Instituto Superior de Ciências Sociais e Políticas Universidade Técnica de Lisboa.

Diz, J., and Luquini, R. (2011). «As relações exteriores do Mercosul: análise das negociações com a União Europeia». Universitas Relações Internacionais, 9(1), 103 to 130.

Dunning, J. H. (2000). «The Eclectic Paradigm as an Envelope for Economic and Business Theories of MNE Activity». International Business Review, Vol. 9, 2, 163 to 190.

Dunning, J. H. (2001). «The Eclectic (OLI) Paradigm of International Production: Past, Present and Future». International Journal of the Economics of Business, Volume 8, 2, 173 to 190 . 
Eichengreen, B., and Irwin, D. (1998). «The Role of History in Bilateral Trade Flows». In J. A. Frankel, Ed., The Regionalization of the World Economy. Chicago: NBER/University of Chicago Press, 33 to 67.

European Commission (2010). «Internationalization of European SMEs». Entrepreneurship Unit, Directorate-General for Enterprise and Industry, of European Commission.

Farinha, L., and Félix, S. (2014). «Uma Análise de Restrições de Financiamento às PME Portuguesas». Artigos de Estabilidade Financeira, Banco de Portugal. November, 1 to 27.

Freres, C. (2005). «La Corta Historia de las Cumbres: 1991-2004». In Arenal, C. D. (Coord.), Las Cumbres Iberoamericana (1991-2005). Logros e Desafios. Madrid: Fundación Carolina, 1 to 26.

Hallén, L., and Wiedersheim-Paul, F. (1979). «Psychic distance and buyer-seller interaction». Originally published in Swedish and then translated into P. J. Buckley and P. N. Ghauri, Eds, The Internationalization of the Firm: A Reader, 2nd edition (1999). London: International Thomson Business Press, 349 to 360.

Hill, A., and Hill, M. M. (2008). Investigação por Questionário (2a Edição). Lisbon: E. Sílabo.

INE (2018). Estatísticas das Empresas 2016. Lisboa. Instituto Nacional de Estatística, I. P.

Johanson, J., and VahIne, J.-E. (1977). «The Internationalization Process of the Firm - A Model of Knowledge Development and Increasing Foreign Market Commitments». Journal of International Business Studies, Volume 8, 1, 23 to 32.

Johanson, J., and Vahlne, J.-E. (1990). «The Mechanism of Internationalization». International Marketing Review, 11 to 24.

Johanson, J., and VahIne, J.-E. (2009). «The Uppsala Internationalization Process Model Revisited: From Liability of Foreignness to Liability of Outsidership». Journal of International Business Studies, 40, 1141 to 1431.

Johanson, J., and Wiedersheim-Paul, F. (1975). «The Internationalization of the Firm Four Swedish Cases». Journal of Managements Studies, Vol. 12, 3, 305 to 323.

Kegel, P. and Amal, M. (2013). «Perspectivas das negociações entre o Mercosul e a União Europeia em um contexto de paralisia do sistema multilateral e da nova geografia econômica global». Revista de Economia Política, 33(2), 341 to 359.

Manheim, J. B. et Al (2007). Empirical Political Analysis Quantitative and Qualitative Research Methods (7th Edition). London: Longman.

Raposo, M. B., Silva, J. R., and Viana, C. (2004). «Internacionalização: uma abordagem na ótica da teoria das redes e dos recursos». Revista Portuguesa de Marketing, Year 8, Vol. 1, 16, 55 to 66.

Return on Ideas (2018). Um Olhar Sobre a Internacionalização das PME. Lisbon. Câmara de Comércio e Indústria Portuguesa.

Reinert, E. R. (2007). How Rich Countries Got Rich ... and Why Poor Countries Stay Poor. London: Constable

Ricardo, D. (1821). On the Principles of Political Economy and Taxation. Library of Economics and Liberty. Retrieved May 20, 2014. [Consulted on 25/02/2019]. Available at http://www.econlib.org/library/Ricardo/ricP.html.

Santos, A. F. F. E. B. (2014). Fatores institucionais na internacionalização das PMEs portuguesas para a América Latina. Dissertação de Mestrado. Instituto Superior de Economia e Gestão - Universidade de Lisboa 
Silva, J. R. (1993). «Desencontros e Caminhos de Convergência». In José Calvet de Magalhães, Álvaro de Vasconcelos e Joaquim Ramos Silva (ed.), Portugal Paradoxo Atlântico: Diagnóstico das Relações Luso-Americanas. Lisboa: Fim do Século edições, 99 to 196.

Silva, J. R. (2002a). Estados e Empresas na Economia Mundial. Lisboa: Editora Vulgata. Silva, J. R. (2002b). Portugal/Brasil: Uma Década de Expansão das Relações Económicas, 1992-2002. Lisbon: Editora Terramar.

Silva, J. R. (2005). «A Internacionalização das Empresas Portuguesas: A Experiência Brasileira». RAE - Edição Especial Minas Gerais, Vol. 45, Special Minas Gerais, 102 to 115.

Silva, J. R. (2008). Internationalization Strategies in Iberoamerica: The case of Portuguese trade. Economic Commission for Latin America and the Caribbean (ECLAC) Project Documents collection. Santiago do Chile: United Nations Publication.

Silva, J. R., Simões, C. C. (2012). «Portuguese Exports and FDI: Observations from the firms' perspective». China-USA Business Review, Vol. 11, 6, June, 820 to 835.

Silva, J. R. (2019). «A economia portuguesa após 2015: O triunfo incerto do modelo improvável». In Allan Claudius Queiroz Barbosa e Cristina Parente (Orgs), Sociologia, Gestão e Economia: Diálogos transversais entre Portugal e o Brasil. Curitiba: Editora CRV, 59 to 81 .

Simões, A. C. (2010). Internacionalização das Empresas Portuguesas: Processos e destinos. Masters dissertation. Lisbon: Instituto Superior de Economia e Gestão, Universidade Técnica de Lisboa.

Trein, F., and Guerra Cavalcanti, F. (2007). «Uma análise crítica do acordo de associação estratégica entre a União Européia e a América Latina e as Caraíbas - A Cúpula de Viena». Revista Brasileira de Política Internacional, 50(1), 66 to 85. 